\title{
PLK4 Gene
}

National Cancer Institute

\section{Source}

National Cancer Institute. PLK4 Gene. NCI Thesaurus. Code C119601.

This gene plays a role in the formation of centrioles or basal bodies. 